Intersections

Canadian Journal of Music

Revue canadienne de musique
Intersections CANADIAN JOURAL OF MUSIC
REVUE CANADIENEE DE MUSIOUH

\title{
Wearing Two Hats: Anne Eggleston as Composer and Pedagogue
}

\section{Roxane Prevost}

Volume 28, numéro 2, 2008

URI : https://id.erudit.org/iderudit/029956ar

DOI : https://doi.org/10.7202/029956ar

Aller au sommaire du numéro

\section{Éditeur(s)}

Canadian University Music Society / Société de musique des universités canadiennes

ISSN

1911-0146 (imprimé)

1918-512X (numérique)

Découvrir la revue

Citer cet article

Prevost, R. (2008). Wearing Two Hats: Anne Eggleston as Composer and Pedagogue. Intersections, 28(2), 72-95. https://doi.org/10.7202/029956ar

\section{Résumé de l'article}

Parallèlement à ses activités créatrices, la compositrice canadienne Anne Aggleston a mené une carrière active en pédagogie du piano. Plusieurs oeuvres, comme Sketches of Ottawa, tentent de combiner ces deux préoccupations. L'examen du Fonds Anne Eggleston (MUS 282), acquis par Bibliothèque et Archives Canada en 1997, aide à saisir la personnalité de cette compositrice remarquable et évaluer son engagement envers la pédagogie du piano. Ses notes de cours et son dévouement envers ses étudiants en privé, de même que son adhésion auprès d'organisations musicales, dessinent un riche portrait de cette importante compositrice et pédagogue.
Tous droits réservés (C) Canadian University Music Society / Société de musique des universités canadiennes, 2009
Ce document est protégé par la loi sur le droit d'auteur. L’utilisation des services d'Érudit (y compris la reproduction) est assujettie à sa politique d'utilisation que vous pouvez consulter en ligne.

https://apropos.erudit.org/fr/usagers/politique-dutilisation/ 


\title{
WEARING TWO HATS: ANNE EGGLESTON AS COMPOSER AND PEDAGOGUE
}

\author{
Roxane Prevost
}

The Canadian composer Anne Eggleston (1934-1994) created works in many genres, but she scored most of her pieces in versions for solo piano or for voice and piano, often with her students in mind. Although Eggleston identified herself primarily as a composer, she also had an active career as a piano pedagogue, teaching piano for as many as fifty hours a week. Many of her compositions bridge the gap between the composer and pedagogue. Works such as Sketches of Ottawa were played by students as part of recitals or juries, as well as by professional concert pianists in recitals.

By examining the Anne Eggleston Fonds, acquired by Library and Archives Canada in 1997, we can better understand her as both a gifted composer and a remarkable piano pedagogue. Her teaching materials and her devotion to private students, her affiliation with music organizations, as well as works such as Sketches of Ottawa will come under study here.

Born in Ottawa, Eggleston was exposed to music at an early age. Her father, Wilfrid, was a well-known journalism professor at Carleton University, while her mother, Magdalena, was a writer. Eggleston began her piano studies with Gladys Barnes and Robert Fleming, and pursued musical studies at the Royal Conservatory of Music in Toronto (1953-1956), studying piano with Pierre Souvairan and composition with Oscar Morawetz, Godfrey Ridout, and John Weinzweig. After obtaining an artist diploma, she completed a master's degree in composition at the Eastman School of Music (1956-1958) under the tutelage of Bernard Rogers in composition and Emily Davis and Orazio Frugoni in piano.

For most of her career, Eggleston considered herself primarily a composer, but clearly she held teaching to be an important part of her musical life, sometimes listing it as her primary occupation. She included advertisements for teaching piano and theory, as well as student recitals, in local newspapers. ${ }^{1}$ In 1965, Eggleston was awarded two scholarships by the Music Arts Club, which she used to study voice and piano pedagogy at the Banff School of Fine Arts. ${ }^{2}$ Harriet Hill in the Montreal Gazette, dated 5 August 1966 explains Eggleston's devotion to teaching:

With her studies helped along by scholarships and a regular confetti of awards, she remains unspoiled. She is an arduous worker as witnessed by

1 Folder 40, box 4, Anne Eggleston Fonds (hereafter EF), MUS 282, Library and Archives Canada.

2 Folder 65, box 6, EF. 
her strenuous music teaching schedule-about 50 pupils a year averaging a teaching day of about seven hours. ${ }^{3}$

The difficulties of wearing the hats of both composer and pedagogue are evident in a letter of 12 June 1966 to Lillian Lee of the Berklee School of Music. In it, Eggleston apologizes for having taken so much time for lesson ten from a twenty-five-lesson correspondence course in "techniques of modern music and jazz, in theory as well as in practice."4

When it arrived, I was right in the middle of preparing five entries for a local CBC composers competition, which had an April 15th deadline. This month and last I have had 20 piano + theory students trying Royal Conservatory of Music in Toronto examinations. Also have 2 student piano recitals to prepare for the end of the month. ${ }^{5}$

Clearly, Eggleston valued pedagogy as much as composition and devoted much of her life to combining both activities.

\section{Teaching Materials}

The Eggleston Fonds give us a glimpse of not only the scope of her pedagogical approach but also the conservation and reuse of pedagogical materials, this dating even back to her days as a student. Eggleston preserved meticulously her class notes from her University of Toronto studies. One section of a notebook consists of notes taken during two semesters of study (October 1957 to February 1958) on the pedagogy of theory. ${ }^{6}$ Throughout the years, she preserved and reused many materials, such as notes for students (in red, green, and blue ink) telling them to bring their books and to not cancel lessons during exams. ${ }^{7}$ Eggleston's approach to teaching was eminently practical, concentrating on particular skills and problems in isolation. Something of this approach can be seen in a list of compositions written for teaching: ${ }^{8}$

Major and Minor for One Hand of the Piano

Up and Down: Four Kinds of Chords

Great Leaps Forward

Left-Hand Variants

Major Scales and Cadences I

Liszt Finger Exercises

Closed and Open Broken Triads

Excepts from Different Composers for Piano

Left-Hand Finger Exercises for the Piano

Major-Minor (right hand) and Minor-Major (left hand)

Octave Patterns

Contrary Dominant Sevenths

3 Folder 114, box 10, EF.

4 Advertisement for correspondence course, folder 40, box 1, EF.

5 Folder 1, box 1, EF.

6 Folder 2, box 1EF.

7 Folder 75 , box 7 , EF.

8 Folder 99, box 8, EF. 


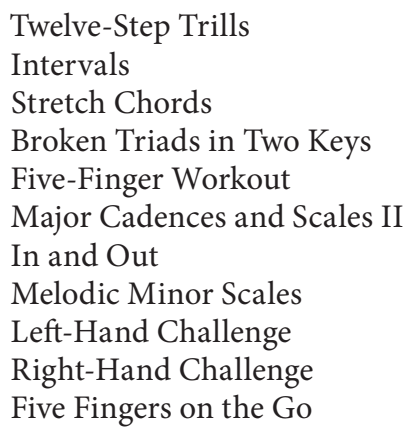

She also wrote Triple-Trouble for piano wherein the right hand plays for only twenty-five measures, followed by left hand for only twenty-five measures; one is the mirror inversion of the other. ${ }^{9}$ None of these are true compositions, but instead drills or exercises to improve specific skills in the young pianist.

Throughout her career, Eggleston was concerned particularly with teaching the student to understand music theory in a practical manner. This concern is reflected again in the titles and subject matter of her pedagogical compositions: ${ }^{10}$

Root Position Major Triads

Dominant Shortkeys (arpeggiated dominant seventh chord on C)

Contrary Dominant 7 th chords: Arm Rotation

Trills: 1st Three Notes of any Scale (includes different fingering for left hand and right hand in top corners)

Rhythms for Minor Scales: Melodic

What To Do at the Cadence (includes durational patterns for $6 / 8$ with one common cadential duration of quarter/eighth/dotted quarter)

Exercises with Line Doubled in Two Hands

Chromatic Crawl in the Keys of C, G, F, D, Bb, A, Eb, E, Ab, B, Db, F\# (pat-

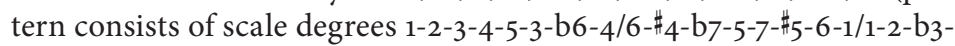
4-5-b4-\#5-3/6-4-\#6-\#4-7-5-b6-1)

Integrated Exercises (two hands are durationally independent)

Also Whole Tone and Chromatic (upper-neighbour exercise)

Thumb Exercises

Patterns for $3 / 4$

Finger Strengthener (pattern begins on $\mathrm{C}_{4}[1] \mathrm{D}_{4}-\mathrm{E}_{4}-\mathrm{D}_{4}-\mathrm{E}_{4}$ [2] E4-F4-E4$\mathrm{F}_{4}[3]$ etc.)

Broken Intervals

Scale with Cadence

Major Tetrachords, Minor Tetrachords, Major 1-5 (scale degrees 1-5), Minor 1-5 Arpeggios, Melodic Minor 5-8

Intervals up to the Major Seventh

Finger Slides: Use Same Finger on Each Group of Two Notes

Root Position Major Triad, Minor Triad, 1st Inversion, 2nd Inversion (broken) 
Octave Pattern

Murky Sounds (harmonic pentachords)

5-Note 7 th Chords

Wrist Twist

Eight Bars Each: Seven Notes Apart; Series II Grades 1-2

Eight Bars Each: Six Notes Apart; Series I

Eggleston also introduced some concepts by drawing on familiar repertoire. "Dotted 8th and 16th Patterns," for example, reproduces excerpts from what Eggleston refers to as Mozart's Minuet in B-flat, Clementi's Sonatina, D. G. Türk's The Echo, French Folk Tune (arranged by Diller Quaile), and Beethoven's Minuet. For "This Is the End: Held Notes and Phrasing," she draws on excerpts from the folksong "The Morning Dew," Granos's Trumpet Minuet, Purcell's Gavotte, Haydn's Minuet in F, Beethoven's German Dance, and Beethoven's Minuet in G. ${ }^{11}$ With the insertion of such excerpts from different repertoire, the young student would be exposed to music and learn specific skills.

In addition to these exercises, the Eggleston Fonds include observations made throughout the years on teaching beginner pianists. The following transcription gives an idea of Eggleston's concern with a young student's psychology $y^{12}$ :

Observations + ideas concerning

- $\quad$ starting to play piano

- one of the very basic problems to clear up is to make sure that the very young starter knows which hand is the right hand, which hand is the left hand

- many beginner books tend to rush through what is being learnedneed more practical work to get students familiar with the keyboard

- hands seem to work better

- $\quad$ After $\mathrm{R}+\mathrm{L}$ hand are sorted out-then the fingers must be sorted out too. Must learn direction that high pitch notes are right, low pitched notes are on the left

- Problem of long notes + long rests in beginners material

- $\quad$ kids like to play + keep going-don't like to measure silences as well as sound

Eggleston preserved these materials as part of the documents she wanted donated to Library and Archives Canada. Struggling throughout her life to reconcile two professions, she wanted to be remembered not solely as a composer, but also as a dedicated piano pedagogue. The materials described here show her commitment to teaching.

11 Folder 142, box 17, EF.

12 Ibid. 


\section{Private Students}

Eggleston included some of her works in her students' recitals. For example, there are reports of her students playing "Parade on Parliament Hill" from Sketches of Ottawa (1962; 1964; 15 June 1972), "Canoeing on the Canal" from Sketches of Ottawa (1962; 21 June 1967), "Seven Studies in Search of a Title" (1963), "Dawn on Dow's Lake" from Sketches of Ottawa (1963; 1965; 21 June 1969), "Running on Rockliffe Park" from Sketches of Ottawa (1963), "Crossing the Champlain Bridge" from Sketches of Ottawa (1964), "The Peace Tower Clock Strikes Thirteen" from Sketches of Ottawa (1964), "By the Colonel By Fountain" from Sketches of Ottawa (1964), "The Bank Street Bus" from Sketches of Ottawa (1965), "Sonatine" (1965; 21 June 1967 [Minuet only]; 27 June 1973), “The Dashing Diplomats' Dance" from Sketches of Ottawa (21 June 1967), "Song for Expo" (27 June 1967), and "Hurry! Hurry! Hurry!" (27 June 1973).13 For Eggleston, then, the composer and piano pedagogue became one. She composed some works with her students or the young pianist in mind. In an article written by Eggleston herself for promotional purposes, she affirms, "Since 1958 she has been teaching piano, theory, and composition privately in Ottawa. This has resulted in a number of works for young performers, including on Citadel Hill (1964) and Sketches of Ottawa (1962) for piano solo."14 The list of miniatures for piano aimed at children is extensive, with many pieces one to two pages in length and with titles that would attract children, such as "The Circus," "The Lion and the Mouse," and "Fun on the Hill."15

\section{Affiliation with Schools and Other Music OrganizATIONS}

Eggleston's involvement with schools and music organizations led to an interest in her music from young pianists and the music community. She taught at the Glebe Centre and the Abbotford House ${ }^{16}$ and would often be invited to attend performances of her works at student recitals. In the promotional article mentioned above, she notes a commission received from the Merivale High School Band for her work Suryanamaskar in 1972. ${ }^{17}$ Eggleston received a letter from the Ottawa Board of Education, written by Isobel Kristijian and Elaine Hokins on 6 February 1979, informing her that her Let's Celebrate for recorders and percussion was to be performed by 400 children on 21 February $1979 .{ }^{18}$ She also received a letter, dated 16 October 1973, from Elsie Melson, the corresponding secretary for the Ontario Registered Music Teacher's Association, informing her that her Sonatine would be performed by Brenda Joe on 23 November at Canterbury High School as part of Canada Music Week. ${ }^{19}$

\footnotetext{
13 Program notes included in folder 23, box $3, \mathrm{EF}$.

14 Folder 40, box 4, EF.

15 Folder 98, box 8, EF.

16 Folder 27, box 3, EF.

17 Folder 40, box 4, EF.

18 Ibid.

19 Ibid.
} 
In addition to her affiliation with regional music organizations, Eggleston was active with an initiative from the Canadian Music Centre. In the Ottawa Journal of 22 February 1964, Jean Southworth writes:

Last fall [Eggleston] was among 14 Canadian composers commissioned by the Canadian Music Centre to write educational music for student orchestra, bands and chords. To fulfill the commission she is now writing a composition for string orchestra, called Variations on a Canadian Folk Song. ${ }^{20}$

She was also chosen as one of fourteen composers for the "Seminar II: Concert Demonstration Program (Graded Music Plan)" on 5 March 1965 with commentator Keith MacMillan, for which she wrote On Citadel Hill. ${ }^{21}$

Eggleston's pieces for piano students were included as part of the Royal Conservatory of Music examinations. She routinely sent materials for consideration in the RCM syllabi and had some success with Seven Variations for piano (Grade 7, list B), ${ }^{22}$ Ethnic Dance for solo guitar (Grade 6 list C), ${ }^{23}$ Hurry, Hurry, Hurry, ${ }^{24}$ and The Old Chateau: Theme and Eight Variations for Piano Solo (Grades 7 and 8). ${ }^{25}$ A program for an event called "Contemporary Showcase ' 76 " includes Hurry! Hurry! Hurry! for "Grades 6-7, Group B," Christmas Song for "intermediate female-medium-401, Group B," and On Citadel Hill for "junior string orchestra-2101, Group A."26 Eggleston received a letter from Don Anderson, publications assistant for the Publications Department of the Royal Conservatory of Music, informing her that Hurry, Hurry, Hurry had been selected for the 1994 syllabus and that other materials she had submitted (Ethnic Dance, Broken Triads in Two Keys I and II, In and Out, Left Hand Variants, Closed and Open Broken Triads, Majorminor, Minormajor, and Twelve-Step) would be considered in the future. ${ }^{27}$ With her reputation well established and pieces included in the RCM syllabi, she was recognized in Ottawa as a leading figure in piano pedagogy, in particular for young children. ${ }^{28}$

\section{SKETCHES OF OTTAWA}

With appealing titles particularly relevant to a child living in Ottawa, Sketches of Ottawa (1962) was also performed by professional pianists. The piece consists of twelve short movements, each with a subtitle, and it was included as part of the Grade 10 Royal Conservatory exams. ${ }^{29}$ The movements are entitled "Parade on Parliament Hill," "Canoeing on the Canal," "Running in Rockliffe

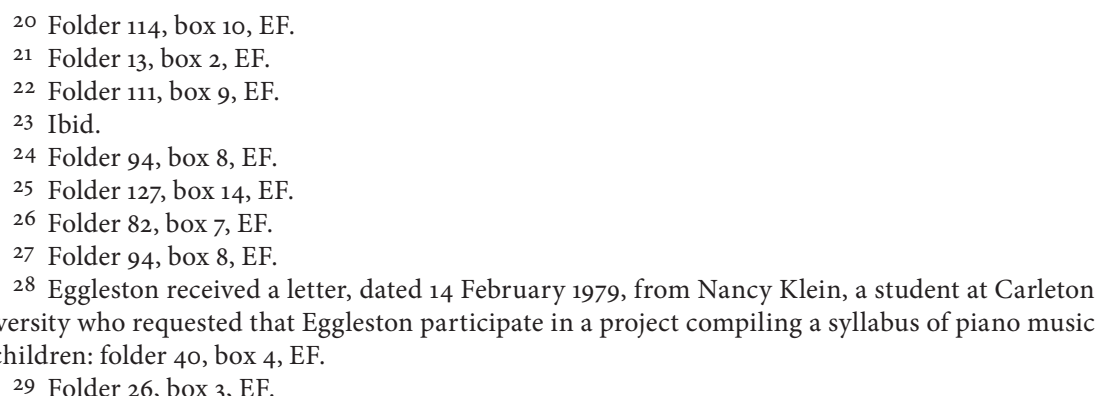

29 Folder 26, box 3, EF. 
Park," "Dawn on Dow's Lake," "The Bank Street Bus," "Tiptoeing through the Tulips," "The Peace Tower Clock Strikes Thirteen," "Crossing the Champlain Bridge," "Gazing at the Gatineau Hills," "The Dashing Diplomat's Dance," "By the Colonel By Fountain," and "Merrymaking on the Mall."

Louise Milota performed the work on 10 December 1971 in Norway. 30 The Penny Press Ottawa writes on 7 November 1976 that the piece was to be included in a recital by Suzanne Chapin on 9 November 1976 at St. John's Anglican Church. ${ }^{31}$ Eggleston preserved copies of concert programs with Suzanne Chapin playing the work at the Winnipeg Art Gallery on 14 November 1976, the Windsor Art Gallery on 6 February 1977, Central Library Oakville Sunday Concerts on 19 December 1976, Daeman College (Buffalo) on 21 December 1976, and at Carleton University as part of "Canada Music Week, Ontario Registered Music Teachers, Ottawa Branch" on 27 November 1976.32

Just how did this work combine performance with pedagogical value? By drawing on landmarks to which a child from the Ottawa region would relate, Eggleston established a familiarity in the child's mind by evoking a specific image. The first movement, "Parade on Parliament Hill," creates the image of a marching band (see ex. 1). The repeated perfect fifth $\mathrm{A}_{2}-\mathrm{E}_{3}$ in the left hand imitates the regularity of the marching band, while the repetition of the melody in different registers imitates the sounds of specific instruments. The motive with the arpeggiated E-minor chord at measure 9 brings to mind the call of a horn or trumpet.

While a child could have imagined a band marching on Parliament Hill, the movement could also have served as a pedagogical tool. With the repeated dyad in the left hand (mm. 1-4), a young pianist could focus on the right-hand melody and observe its dynamic markings and slurred articulation. A student would also be introduced to the ternary design by a melody in common time surrounding a contrasting middle section in three. To highlight the middle section, Eggleston replaces the repeated $\mathrm{A}_{2}-\mathrm{E}_{3}$ dyad in the left hand and the stepwise melody in the right hand with new dyads and triads in the left hand and an arpeggiated horn motive in the right hand. By means of such a short, simple movement, Eggleston could refine her students' playing by focusing on clearly expressed dynamics, articulation, clef changes, changing time signatures, and small formal designs.

"Canoeing on the Canal" evokes the movement of paddles in and out of water through a repeated motive in the left hand of measures 1-12 and 19-24, and in the right hand of measures 13-18 (see ex. 2). The long melodic lines might represent a breeze on a warm summer day. From a technical perspective, these two characters challenge students' hand coordination, and simple variations to the melodic material keep the students on their toes. The two hands, for example, coincide on the last eighth note of the first measure; there the left hand completes a repeated two-note pattern, but the right hand leads smoothly onward to the next measure. At measure 13, the hands are reversed; the left hand takes

\footnotetext{
30 Folder 41, box 4, EF.

31 Folder 65, box 6, EF.

32 Folder 82, box 7, EF.
} 

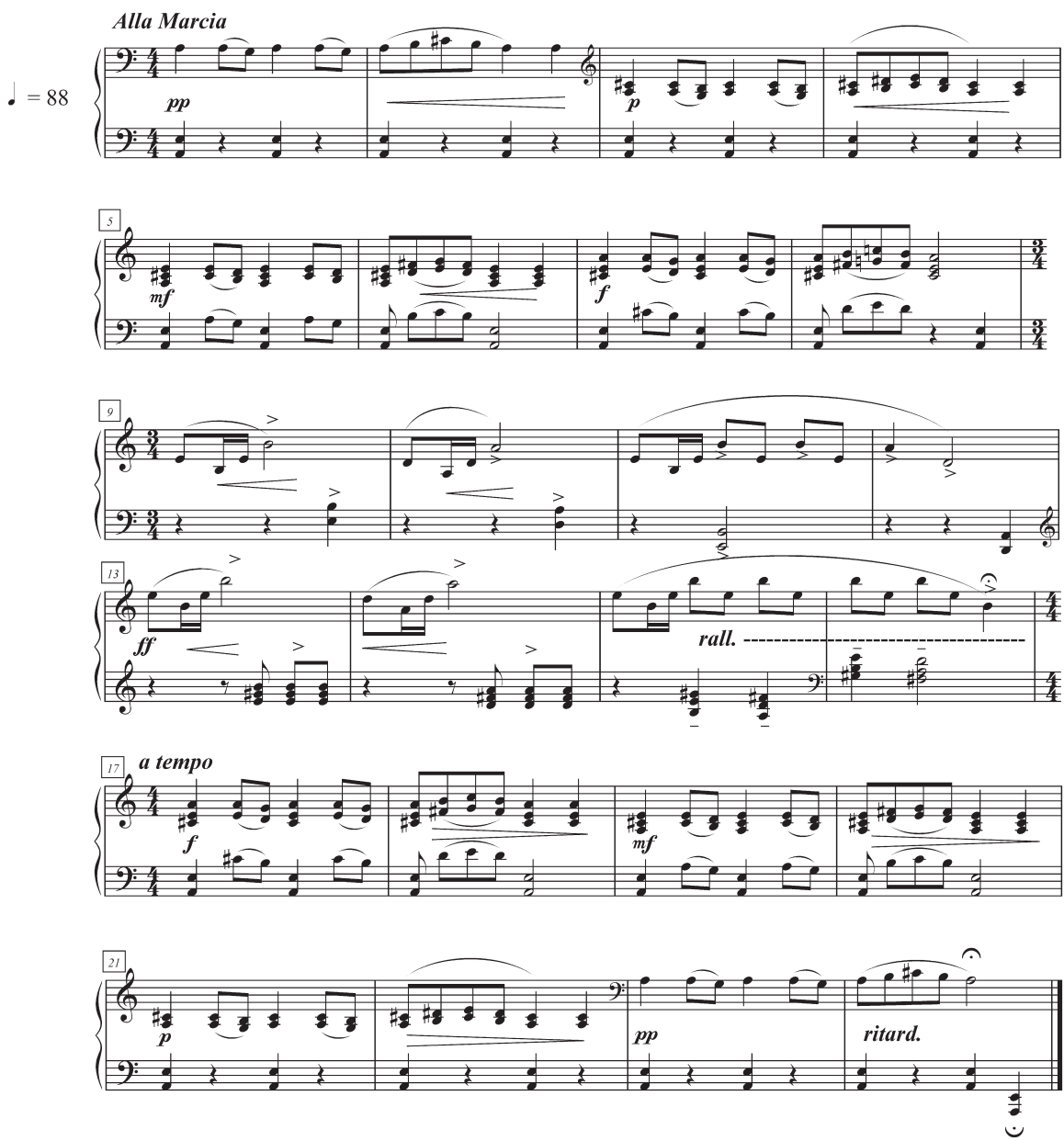

Example 1: Eggleston, Sketches of Ottawa, first movement, "Parade on Parliament Hill"

over the melody, while the right hand plays the accompanying two-note figure. The melody now begins on $\mathrm{C}_{5}$, a sixth higher than the original, and it changes in intervallic pattern in measure 14 . By measure 15 , the right hand plays the same $\mathrm{A}_{4}$ as in the original (m. 3), but with the eighth-note $\mathrm{G}_{4}$ the pattern falls one scale step lower than the original. The leap of the major third instead of major second at the end of the line (mm. 17-18), allows it to end on $\mathrm{D}_{4}$, as in the original. While the right hand at measures $13-16$ is similar to the opening left hand, the pitch classes and contour are inverted. Instead of $\mathrm{B} b_{3}$ leaping down a perfect fourth to $\mathrm{F}_{3}, \mathrm{~F}_{5}$ leaps up to $\mathrm{B} b_{5}$. By measure 14 this pattern has been disrupted, but the ascending leaps of a perfect fourth prevail until the end of measure 16 . At measures 17-18, the downward contour of the original pentachord with its perfect fourths is replaced by an upward contour with perfect fourths. The two lines return to their original hand placement at measure 19 with the restatement of the opening. The piece challenges students to focus on compound metre, the 


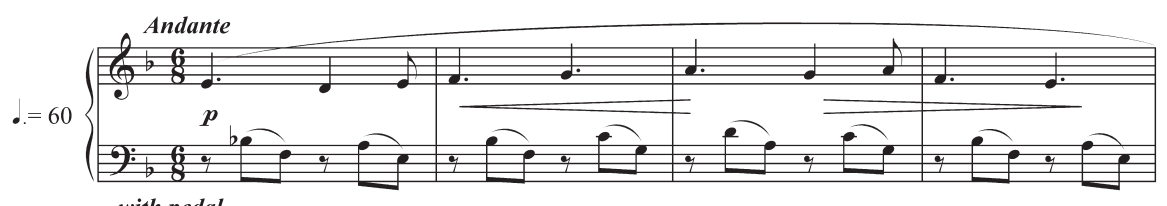

with pedal
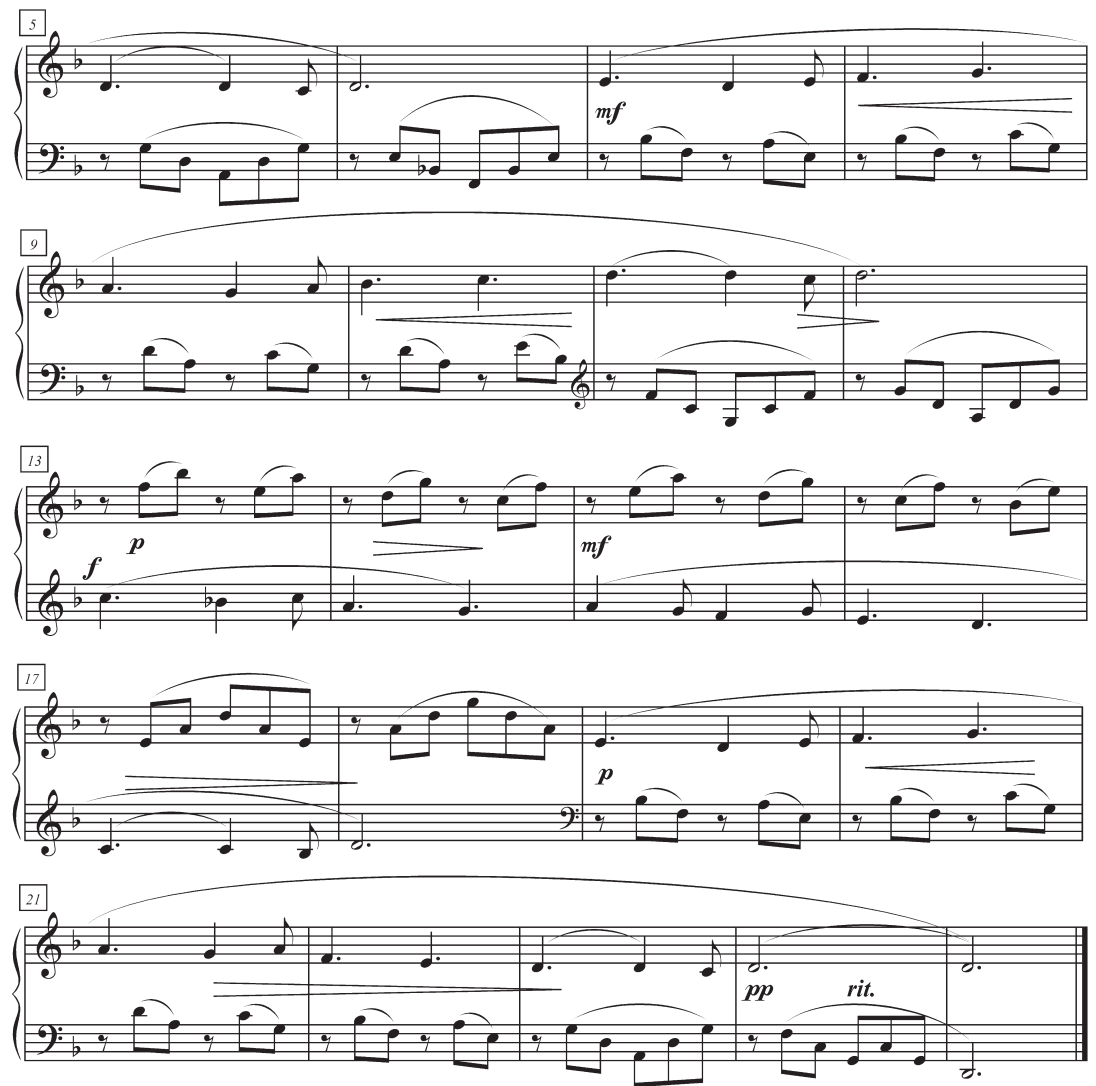

Example 2: Eggleston, Sketches of Ottawa, second movement, "Parade on Parliament Hill"

pedal, and hand coordination, all the while requiring of them a recognition of altered material, once more in a ternary design.

"Dawn on Dow's Lake" evokes the image of the sun rising on the water, but the rhythmic effect of the piece is anything but placid. To the student's mind, the sustained notes and high register in the left hand might represent the calmness of dawn, while the repetitive two-note pattern in the right hand represent the ripples in the water (see ex. 3). The sun's rising and a consequent increased activity on the lake are projected through the introduction of triplets and by increased dynamics. This movement explores the contrast of duple and triple groupings. The beginning clearly establishes the duple subdivision with running eighth notes, but at measure 9 Eggleston groups the eight notes in threes with slurs, followed by one measure of triplet-eighth notes, a return to the slurred eighth notes, and four measures of triplet-eighth notes. Regular 
eighth notes, returning at measure 17 , persist until the end, but a shift occurs with the half note in the left hand, which now falls on weak beats in measures 22-23. The last measure ends with an eighth-note fermata, suggesting a short pause before the opening of the following movement, which begins with the same bass note. This movement would be particularly useful in learning to play and hear two different metres or groups of notes: measures 1-8 are clearly in a simple triple metre, but by measure 9 one could conceive of this measure in $6 / 8$. The triplets that follow force the student to alternate between duple and triple groups of eighth notes. By measure 13, a student could think of the duple eighth-note subdivision as the equivalent of the dotted quarter note, which is then divided into three eighth notes (the triplets of m. 9). In essence, measures $12-15$ could be interpreted as the equivalent of $9 / 8$. Since many pitches repeat, the student is free to focus on these rhythmic and metrical subtleties. One could also focus on dynamic changes, since Eggleston moves from pianissimo all the way to fortissimo within this short movement.

The $5 / 8$ metre, running eighth notes, and chromatic lines of "The Bank Street Bus" no doubt are intended to portray a busy bus and its numerous passengers. Eggleston maintains the $3+2$ division throughout the movement in the left hand, but the tied notes over the bar line would challenge the student, as would the accidentals and chromatic lines throughout and the division of two lines in the right hand (mm. 4, 8-9, 21, and 25-27). Here, the student learns to focus on an unconventional metre and upon hand coordination. Perhaps most important from the perspective of a contemporary composer, however, is the post-tonal idiom of the work. While relating the piece to personal experiences, students would also be exposed to new sounds and scales. Works like these no doubt have many pedagogical benefits, but they appeal as well because of their charm, evocation of images, and careful use of modern harmonic idioms such as these.

\section{Conclusion}

Although Eggleston strived to be recognized as a composer and piano pedagogue, she had to relinquish both in her early fifties on account of deteriorating health. On a "Statement on Earnings as Music Teacher and Composer," Eggleston begins, "Because of two serious illnesses-meningitis and encephalitis-I was ill for a large part of 1984."33 On 12 August 1987, Eggleston received a letter from the Canadian Music Centre informing her that no financial aid was available for senior or handicapped associates for performances of their works. This left her in a difficult financial position in terms of promoting her works. ${ }^{34}$ She was admitted to hospital on 20 April 1988 because of a weak left arm and speech difficulties. Her mother writes in a letter dated 2 May 1988 that her daughter had suffered a stroke .35 Her inability to teach and compose proved difficult. As an article written earlier attests, she thrived on these two professions:

\footnotetext{
33 Folder 88, box 7, EF.

34 Folder 31, box 3, EF.

35 Folder 48, box 5, EF.
} 

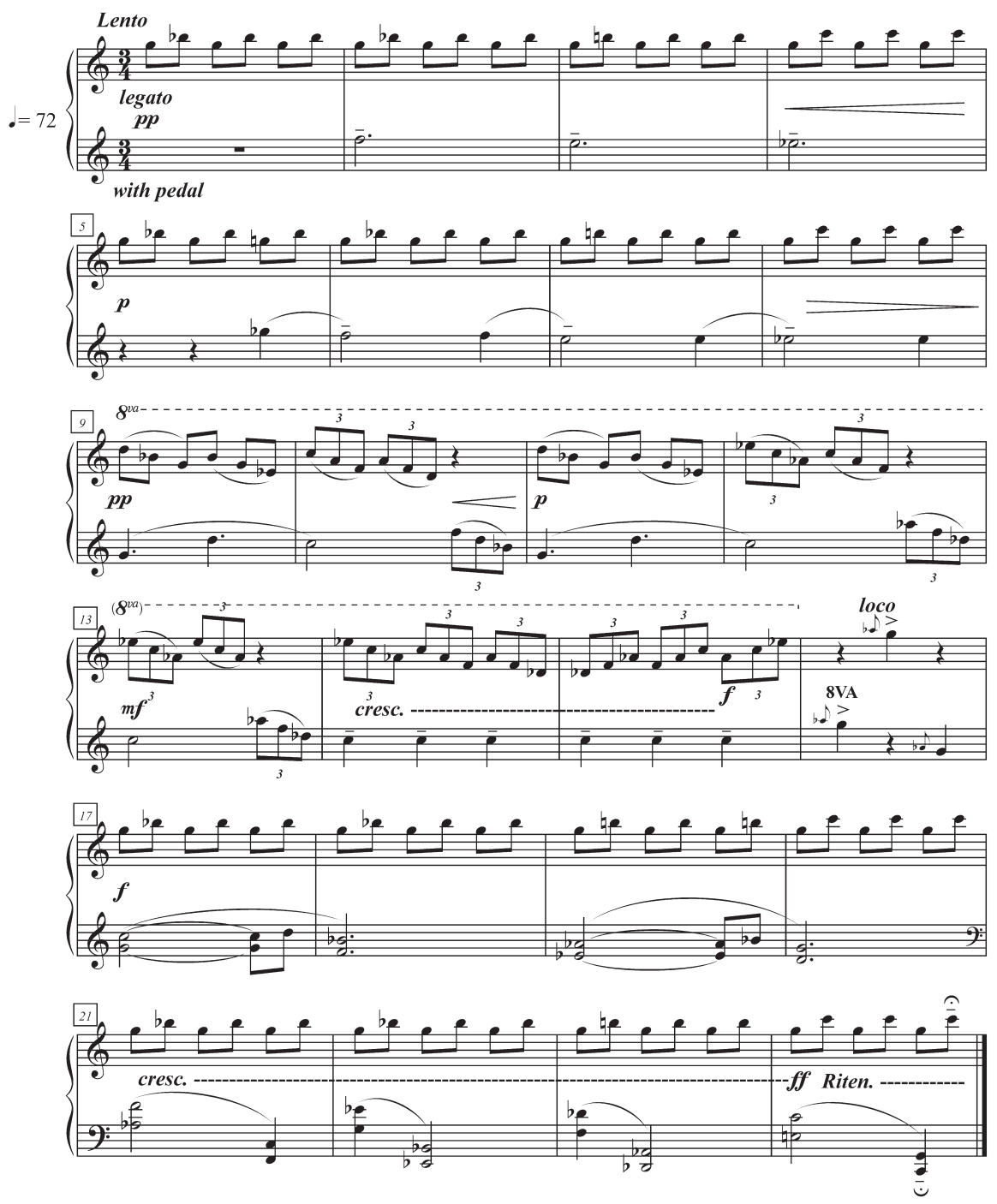

Example 3: Eggleston, Sketches of Ottawa, fourth movement, "Dawn on Dow's Lake”

Composing is a special interest of Anne's but she finds time to teach piano and other subjects. Last winter she had between 50 and 60 students. Though her primary instrument has always been the piano she has studied a number of others, notably the viola (as a student of Dr. J. Berljawsky), the violin, the recorder and guitar. Though most of her training has been in the classical field she has also been a serious student of jazz music. ${ }^{36}$

In the years intervening since her death, however, Eggleston's reputation as a pedagogue has declined dramatically and it is largely Anne Eggleston the 

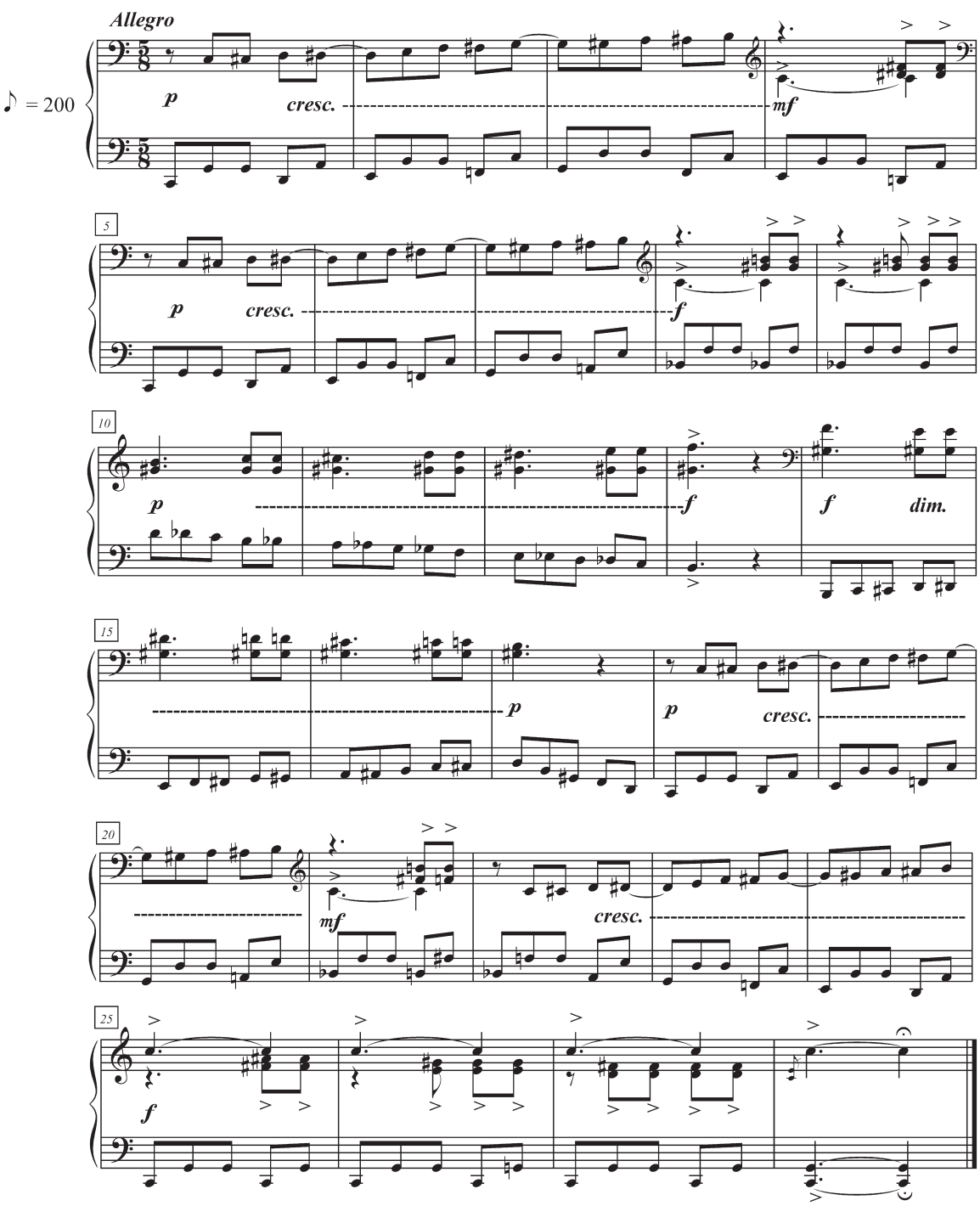

Example 4: Eggleston, Sketches of Ottawa, fifth movement, "The Bank Street Bus"

composer who remains known. Although she took much pride in her hometown of Ottawa and composed works with titles referring to locations in that city, perhaps being situated outside the main cultural centres left her at a disadvantage in the promotion of her works. The legacy materials archived at Library and Archives Canada, only a few of which are touched upon here, attest to the importance this wonderful composer and pedagogue.

\section{ACKNOWLEDgement}

I thank the staff of Library and Archives Canada, Music Division, for their assistance in my study of the Anne Eggleston Fonds. 


\title{
Appendix: Eagleston Fonds, Library and Archives Canada
}

\author{
Box Folder Description \\ 11 Berklee School of Music correspondence: letters and promotional material 1963-1967; \\ lessons with corrected assignments and questions from Eggleston \\ 2 University of Toronto class notes: theory, composition, counterpoint, orchestration, cal- \\ ligraphy, pedagogy and psychology, history; list of compositions studied (Fauré, Brahms, \\ Beethoven, Bach, Ravel, etc.) \\ 3 Quotations collected by Eggleston: "Distilled Wisdom": A Choice of Quotations Collected \\ by Anne E. Eggleston
}

4-5 Press clippings on international contemporary composers

6 Press clippings (miscellaneous music-related): cartoons, columns; none on Eggleston; reform of music notation; "Index of New Musical Notation;" bitonal chord progressions

$7 \quad$ Press clippings

8 Glenn Gould: articles and press clippings that Eggleston started collecting when she began teaching

9 Berklee School of Music correspondence: lessons 16-20; graded assignments

10 Press clippings on contemporary pianists

\begin{tabular}{|c|c|c|}
\hline \multirow[t]{3}{*}{2} & 11 & Press clippings on contemporary pianists; concert programs \\
\hline & 12 & Press clippings on contemporary pianists; cartoons \\
\hline & 13 & $\begin{array}{l}\text { Canadian Music Centre correspondence: letters 1962-1971 on copyright with microfilm } \\
\text { distribution and various performances; general correspondence from the CMC on the } \\
\text { process for submitting scores; request for unpublished scores suitable for use in graded } \\
\text { educational work; composers chosen for Seminar II: Concert Demonstration Program } \\
\text { (Graded Education Music Plan) on } 5 \text { March } 1965 \text { with commentator Keith MacMillan; list } \\
\text { of the Canadian League of Composers with addresses (1971) }\end{array}$ \\
\hline
\end{tabular}

14 Canadian Music Centre newsletters

15 Press clippings on contemporary composers

16 Press clippings on contemporary composers and miscellaneous musical subjects

17 Songs texts; texts by Duncan Campbell Scott, Wilfrid Eggleston, Magdalena Eggleston; published privately (1978) by the Bhakti Press (Ottawa): poems by Wilfrid Eggleston, Bliss Carmen, Archibald Lampman, etc., mainly about Christmas and Canada; missing first two pages of text for "The Wood Carver's Wife" (opera); "An Unfinished Diary": nursery rhymes with keys for Barb Ross (maps keys on words; some with keys and time signatures; some with number of parts)

18 Notes and brochures on arthritis, allergies (injections, tests, serum), meditation, feet care, exercise, and allergy to cigarettes (ear infection); personal notes

19 Press clippings on UFOs, allergies, smoking, exercises, etc.; notes on "Yoga Scientific (1971)," 4 March 1971 to 27 April 1972; test on "Meditation Experiences," 6 July 1971 to 29 July 1972

20 Letter from piano technician; press clippings that are piano related (pianos, teaching); cartoons

321 Miscellaneous press clippings on music; cartoons

22 Quotations organized by category

23 Student recital concert programs (Eggleston's students)

24 Information package for the Cowling system from the Cowling Institute for developing strengths and flexibility in the hands and fingers ("Finger Magic")

25 Promotional material for keyboards (piano, harpsichords, etc.); responses to inquiries from Eggleston; press clippings for keyboards 
Box Folder Description

26 Correspondence on program notes and scores for concerts of Eggleston's pieces; personal correspondence not related to music

27 Correspondence from the Glebe Centre and the Abbotford House where Eggleston taught and volunteered; press clippings on the elderly

28 Berkley School of Music correspondence course: lessons 21-25 with corrected assignments

29 Press clippings on carillon recitals with "Ascent" performed by Percival Price; carillon press clippings; press clipping on Eggleston donating $\$ 50$ for a prize to be given to an "Outstanding Competitor" in the Composition Class of the Ottawa Music Festival (Anne Eggleston Trophy)

30 Press clippings on cleaning tips, recipes, growing old, etc.

31 Canadian Music Centre letter (12 August 1987) informing Eggleston that there is no aid for senior or handicapped associates

32 Canadian Music Centre correspondence: 1989 CMC acquisitions; list of associate composers (eight from Ottawa)

33 Correspondence from parents

434 Correspondence: Canadian Conference of the Arts seminar; Canadian League of Composers

35 Correspondence: Canadian League of Composers; copyright documentation

36-37 Quotations assembled by music categories

38 Eggleston's collection of Christmas articles, pictures, and cartoons from different sources; Christmas songs (traditional); Christmas songs with music by Eggleston and texts by various authors written in two voices

39 Guitar materials: guitar technique exercises; multiple arrangements by Eggleston for guitar; guitar compositions by Ken Davidson; press clippings for the guitar

40 Correspondence: letters from Radio Canada International and the Canadian Broadcast Corporation regarding concerts and recordings; letters from individuals and organizations regarding concerts or participation in projects; letters from publishers declining to publish her works; correspondence (newsletters, etc.) and newspaper clippings (advertisements for teaching piano and theory, Eggleston student recital)

41 Correspondence with pianist Louise Milota; press clippings for Milota's performances and one for Pierre Souvairan; score for "The River in the Pines" (tune of Swedish origin"), "Shady Grove," "Down in the Valley," and "The Dreary Black Hills;" concert program notes for a concert by Milota

42 Correspondence with friends (letters and cards); programs for student concerts

43 Correspondence with friends; concert programs

44 Correspondence with the $\mathrm{CBC}$ in an attempt to get her works played and recorded

45 Correspondence with publishers in an attempt to get her works published

46 Correspondence (life insurance, piano purchase, etc.); miscellaneous press clippings

$547 \quad$ CAPAC correspondence: program notes for Quartet for Piano and Strings (1955) and String Quartet (1957)

48 Miscellaneous correspondence: information on carbamazepine (epilepsy, face pain); charitable donation receipts; needed home care in 1988 (Ottawa Home-Care Programme); letter from Laurine Elkins-Marlow from Texas (1988) informing Eggleston that she has been included in a Catalog of Orchestral Works by Women; letter from Ina Dennekamp regarding the History of Canadian Women; Musica Camerata 1987-88; stroke confirmed in letter by Magdalena Eggleston on 2 May 1988

Correspondence from the Canadian Institute for the Blind confirming that Eggleston qualifies for the services 
$51 \quad$ Notebook with money owed and repayment scheme; rent to mother; Canada Savings Bond; planner for miscellaneous

52-57 Notebook for music lessons and payment schedule

58 (Relocated to Wilfrid Eggleston Fonds)

59 Collection of quotes about birds dedicated to her mother (23 August 1986)

60 Study notebook (diary/journal) with schedule of classes and concerts (27 September 1954 to 5 January 1955)

\begin{tabular}{ll}
\hline 61 & Notebook on piano teaching and miscellaneous; small diary from 1 January 1953 to 13 \\
62 & Leag 1953 \\
63 & Yearbook for Lux Glebana (1951-1952) \\
64 & Yearbook for the Eastman School of Music (1958)
\end{tabular}

65 Press clippings on the Anne Eggleston Trophy; press clippings for premiere of Toccata and performances of Antique Suite for two recorders and piano, Songs from Deepwood, The Reed Player, Five Lullabies, Rhapsody for Violin and Piano, Sonatine, Sketches of Ottawa, Quartet, Blue Flute; press clippings on Ottawa composers for teaching materials, includes Eggleston's Seven Variations; miscellaneous clippings

$66 \quad$ Promotional material for 1988 with a list of selected works

67-69 (Relocated to Wilfrid Eggleston Fonds)

70 Correspondence: rejection letters from editors for a collection of quotes; letters from politicians in response to receiving a copy of her "We Are One"

71 Booklets: press ethics and freebies; directory for the Federation of Musicians in OttawaHull (1965-1966)

72 (Relocated to Wilfrid Eggleston Fonds)

73 Notebooks: address book; notebook with notes on personal photos taken 8 October 1972 to 16 October 1982

$74 \quad$ Yearbook for Lux Glebana 1949

Miscellaneous: invitations to weddings; notes for students (in red, green, and blue) telling them to bring their books and to not cancel lessons during exams; notes on the electronic studio at the University of Toronto; note from the National Library Ottawa about an exhibition on Healey Willan; note on Crawley Films Limited; note on the Canadian Information Service; summary of sight reading from B. Rowbakines Pedagogy Class in Banff (summer 1963); note from Dr. Montgomery about a skin tumour he removed (dated 3 July 1980); program notes (String Quartet); University of Toronto alumni correspondence; transcription of an excerpt from "Time Touch Me Gently" by Mel Thistle (September-October 1965); miscellaneous music quotations organized by category; quotations from the Ottawa Citizen (5 July 1974) on bilingualism; list of bonds bought at the Royal Bank; list of expenses (personal library, office supplies); notes for her will; list of columns (some of them typed) written by Wilfrid Eggleston for the Ottawa Journal in the past ten years (over five hundred of them) and submitted to Borealis Press; miscellaneous notes; Quintessence for Piano (list of diagrams with instruction below); notebook with scribbles; quotations on the piano, pianist, and keyboard; Christmas card and thank you card

Study notebooks: practice notes from piano teacher dated June 1949; notebook for theory and harmony dated 1949 (specific topics)

Biographical documents: promotional material on the first performance of the Piano Quartet on 28 February 1959 in the Fisher Park High School Auditorium sent to the West End Times, South Ottawa Gazette, Le Droit, and The Carleton; list of compositions, instrumentations, etc. (July 1961); biographical notes on early childhood; copy of transcript from the Faculty of Music, Royal Conservatory of Music, University of Toronto; proofs and correspondence for biography in Canadian Who's Who (1986, 1987, 1988); biographical notes from the Encyclopedia of Music in Canada, University of Toronto Press; program for CAMMAC Ottawa-Hull's "Ottawa Composers' Night" at the Glebe Community Centre 
Box Folder Description

78 Miscellaneous press clippings: press clipping for performances of Eggleston's works, mainly in Ottawa, but also across Canada

79 Press clippings and concert programs; clippings about women in music; clippings on violins and violinists; viola study (four-page manuscript)

80 Correspondence with parents; correspondence with CMC on upcoming workshop, transparencies of works to be included in the CMC library, and performances of her works; recital program (1989) of Beverley Gertsman with Sonatine; correspondence about insurance; correspondence about getting Wilfrid's works published (or republished); request from MA student to have Eggleston as part of a "survey on blocks in musicians"; letter and receipt from the Royal Conservatory of Music for a donation of $\$ 50$ to the Dr. S. Dolin Composition Scholarship (22 February 1988); invitation by the Ottawa Board of Education for the concert 3 June 1983 that will include "Night on the Ottawa River" (31 May 1982); CMC correspondence about funding for the arts; correspondence from the Ottawa Curling Club (Relocated to Wilfrid Eggleston Fonds)

Concert programs; reading by Magdalena Eggleston for the Dramalodic Music Club (January 1957); performances of the String Quartet; Musical Art Club in aid of the scholarship fund (2 April 1962); concert programs for student recitals with one of Eggleston's pieces (Canterbury High School); concert programs with Eggleston's works (across Canada); program for "Contemporary Showcase '76: Syllabus;" recital program for Eggleston's students, 12 June 1975

Yearbook Lux Glebana 1950

Stratford Festival: 1966 concert programs for Don Giovanni, Henry V, and Twelfth Night; information booklet for Stratford, Ontario; leaflet for the Carleton University Women's Association; leaflet for the Carleton University Women's Association interest groups (music club is one); leaflet for the New Piano Quartet; concert programs for Eggleston's works (across Ontario). Press clippings: one mentions Eggleston composing a piece for the Charlottetown Festival with a photo (Ottawa Journal, 4 June 1966); another mentions Eggleston's piece "Fanfaron" (Ottawa Citizen, 23 July 1966); concert review of the Piano Quartet at Queen's University Chamber Concert Series in the Kingston Whig Standard in October 1966, entitled "Ovation Accorded to Composer"; article in the Gazette, 5 August 1966 by Harriet Hill featuring Eggleston

85 Report and analysis of needs assessment for the hearing impaired community in Cape Breton, Nova Scotia (10 August 1982); assessment hearing impaired research report (May 1983)

Journals and magazines: Saturday Review (May 17 1988); Music across Canada (March 1963); Le Compositeur Canadien / The Canadian Composer (July-August 1967, no. 20): Eggleston mentioned in the section "CAPAC Composers in the News" with a photo

Quotations entitled "The Bedside Books of A. E." organized in categories: (1) Evening, (2) Night, (3) Sleep, (4) Dreams, (5) Moon and Stars, and (6) Morning

Anne Eggeston Trophy for Composition-Class 120 (from the Ottawa Music Festival Syllabus, 1963); correspondence to the Ministry of Health; health insurance documents; annual income; text for "Vestigia" by Bliss Carman; Ottawa Music Festival programs with names such as "Professor Boris Roubakine" underlined; list of guests for new chamber music ensemble party; clippings from Musicanada on contemporary composers; texts written by Wilfrid Eggleston and chosen by Anne Eggleston; summaries of different dances and genres; musical resumé for Eric Levy; religious texts; "Silent Night" score; notes from Recreation and Parks, Ottawa; article on the piano in the twentieth century written by Robert Ehle; University of Toronto Royal Conservatory of Music of Toronto Requirements for Examinations in Viola (1979); account of programs for the New Chamber Music Ensemble (January 291959 to March 11 1959) and list of names to whom Eggleston gave a copy; "Statement on Earnings as Music Teacher and Composer"; invitation by the lieutenant-governor of Ontario and Mr. Donald W. McGibbon to a reception 
$889 \quad$ Correspondence and materials related to Eastman: invitation card to Eastman convocation (1958); course schedule; final examination for master of music on 22 May 1958; admissions correspondence for master's (1957) and PhD (1960); report cards for 19571958; lyrics for annual carol sing (three pages); concert programs that include Eggleston's pieces; press clipping of two women plotting to blow up the Eastman School of Music (Ottawa Citizen, 3 October 1966); one-pager listing the entries for the 1958 Arthur B. Benjamin Award; student booklet with information on Eastman

90 Correspondence from Robert Fleming: letter from Robert Fleming to Magdalena Eggleston (21 August 1950) to give update on Eggleston's progress and potential as a composer; correspondence between Fleming and Eggleston; entry in the Canadian Music Journal (Autumn 1956) for Fleming's "Secrets: Three Songs" for \$1.00; letter from M. W. Mackenzie (12 June 1979) thanking Eggleston for her support for the Robert Fleming Memorial; pamphlet with information on the Robert Fleming Award for Young Composers; articles on Fleming in Canadian Composer and press clippings; information for Robert Fleming Memorial; concert program for the Church of St. Matthias listing Fleming's works within a mass (30 November 1976)

91 Diary for 1984 (turning fifty): 1 January 1984 to 18 March 1984; 19 March 1984 to 22 May 1984; May 1984 to 25 August 1984; December 1984 to 28 February 1985

92 Diary: 1 March 1985 to 26 June 1985; 27 June 1985 to 24 October 1985; 25 October 1985 to 29 November 1985

Diary: 1 October 1986 to 14 May 1987 (with many spelling mistakes)

Miscellaneous correspondence and documents: invitation cards for Mr. and Mrs. Eggleston; poems: "The Fifth of October," "The Squaw's Lament," "The World's Call" (written by Magdalena); Eggleston family tree; printouts for a computer program on rudiments and notation; correspondence between Magdalena and various individuals; activities for February 1968; letter from Jane Westgate at the Royal Conservatory of Music acknowledging receipt of "Sketches of Ottawa," "Sonatine," "Seven Studies in Search of a Title" (30 August 1990); concert program for the Canadian Piano Quartet who are playing Eggleston's Piano Quartet as part of the Aesculapian Society at the University of Ottawa on 21 November 1963; assignment from Theory 221 ("Pedagogy of Theory") dated 14 November 1957 with definitions and essay questions; text by Wilfrid Eggleston entitled "Christmas Causerie" (1949); list of pieces by Eggleston; short biography; list of selected works; press clippings for Crowsnest Pass, Alberta (gifted athletes, community volunteers, various) and obituary; letter from Bernard Ostry, Canada Day Committee (16 May 1977) thanking Anne and Magdalena for sending "We Are One"; letter from Magdalena to Brian Frappier, producer of This Day at CBOT, СBC (19 March 1977) thanking him for producing "We Are One” with Dillon O'Connor singing it; letter to Eggleston from Mrs. S. J. Kennett from the Ottawa Music Festival Association (12 August 1963) about the trophy in her name; poem "The Instruments of War"; program for students of Eggleston on 12 June 1975; concert programs featuring some of Eggleston's works; Theory 221 (Pedagogy of Theory) assignment; correspondence with Don Anderson, editor for the Publications Department of the Royal Conservatory of Music; score for "Fanfare for CAMMAC" for piano included in CAMM UNI QUÉ (April 1972) [bulletin]; Ottawa Music Festival Program 1973

New Canadian Encyclopedia Publishing (Magdalena) correspondence: contract between Magdalena Eggleston and the New Canadian Encyclopedia Publishing (10 March 1982) to write an article on "Lithuanians"; 200 words for article; letter from James H. Marsh, editor-in-chief for the New Canadian Encyclopedia Publishing (2 March 1982) requesting that Magdalena write an article on ethnic groups; notes from Magdalena on the article

Miscellaneous: press clippings on the Ottawa Music Festival results; "Faces of Ottawa: Anne Eggleston," by W. Q. Ketchum, Ottawa Journal (8 August 1970); press clippings on Pass, Alberta, talented young pianist, peace conference, articles by Wilfrid Eggleston, and various; "Classical Music Has Become Too Pompous ... Says Itzhak Perlman, Virtuoso Violinist and Musical Iconoclast" by Kirk LaPointe, Fugue (October 1977); "Attitude and Performance: Historical Notes and Commentary" by Jerome Stanley, Piano Quarterly (Winter, 1976-1977); copy of Musicanada, 1967; drafts of poems; notebook with food intake for 9 July to 23 August (19??); pocket score for Stravinsky's "In Memoriam Dylan Thomas" with row segments identified, while at Eastman School of Music, 1960 


\section{Box Folder Description}

$97 \quad$ Arrangements: works from various composers; slow movement from Symphony No. 1 by Gustav Mahler for two pianos; Scherzo from Symphony No. 1 by Mahler for two pianos; "La Marseillaise" by Rouget de Lisle for piano; "Vergebliches Ständchen" (The Discomfited Suitor) by Johannes Brahms for violin and piano; scores copied by hand for guitar, piano, violin, viola (Bach, Diabelli, Garcassi, Mahler); "The Troubadour" by Moussorgsky for viola and piano; Prelude by J. S. Bach for guitar and recorder (flute); Sonata in C by Brahms for piano duet; major/minor for piano; French-Canadian folk songs for the piano; Prelude in A (WTC I) by J. S. Bach for violin and piano; "O Canada" by Calixa Lavallée for piano; Study in D by Fernando Sor for piano. Folk songs from different nationalities recopied; "A Piece of Grieg" for piano; piano arrangements of well-known songs ("Frère Jacques," "Twinkle, Twinkle Little Star"-twelve pages); Chaconne by Handel, Variations 48-50 for piano; list of folk songs; Moderato in A Minor by Giuliani for piano; Andante in $C$ by Carcassi for piano; Presto in D Minor by Mattro Carcassi for piano; Allegretto in $E$ Minor from Sonata op. 14, no. 1 by Beethoven for violin and piano

98 Musical works: Blue Flute; The Circus for piano; The Sleeping Beauty for piano; The Lion and the Mouse for piano; Fun on the Hill for piano; The Magic Word for piano; Jumbo for piano; The Wise Jackal for piano; Father's Work for piano; Wings for piano; The Miller, His Son and Their Donkey for piano; Long Ago for piano; The Robin's Nest for piano; The Fox and the Grapes for piano; The Wind and the Sun for piano; The Fox and the Ducks for piano; The Little Match for piano; Belling the Cat for piano; Town Mouse and Country Mouse for piano; The Snowman for piano; Woolly-Bear Caterpillar for piano; An Old Carol for voice and piano (words: anonymous; December 1987); A Feast of Song for two voices? voice and piano? (words by Wilfrid Eggleston; 1974); Season's Greetings for voice and piano (December 1972); Christmas for voice and piano (words by Magdalena Eggleston; December 1971); December Bells for voice and piano (words by Magdalena Eggleston; December 1973); The Star for voice and piano (words by Magdalena Eggleston; December 1976); Carol of the Birds for voice and piano (words by Magdalena Eggleston; February 1975); Nature's Treasures for voice and piano (words by Magdalena Eggleston; February 1977); Tell Me Again for voice and piano (words by Wilfrid Eggleston; February 1979); Christmas Returns for voice and piano (words by Wilfrid Eggleston, December 1982); Come a Little Closer for voice and piano; In the Years of Your Singing for high voice and piano (words by Winnifred Horne); Mountain Sketch for voice and piano (words by Wilfrid Eggleston); Christmas Cards for voice and piano (words by Magdalena Eggleston, December 1989); What Would Christmas Be? for voice and piano (words by Wilfrid Eggleston; December 1981); The Tree for voice and piano (words by Magdalena Eggleston; 1980); Christmas Magic for voice and piano (words by Magdalena Eggleston; 1986); Christmas Morning for voice and piano (words anonymous; December 1984); Prelude for piano (two pages); Slow March for flute and cello; A Frog He Would a Wooing Go for flute and cello (arranged by Eggleston); Four Notes Only for solo flute; Lullaby for cello and piano; Land of the Silver Birch for flute, cello, and piano (arranged by Eggleston); A Gentle Rain for cello; Tarentella for flute and piano; Christmas Trees for voice and piano? (words by Magdalena Eggleston); O Christmas Tree for piano; We Three Kings for piano; Christmas Flowers for voice and piano (words by Magdalena Eggleston; February 1978); The Christmas Bells Ring Out for Peace for piano (December 1983)

Exercises and notes: major and minor for one hand of the piano; "Up and Down: Four Kinds of Chords"; "Great Leaps Forward"; "Left-Hand Variants"; "Up and Down; Major Scales and Cadences I"; graded assignment for CTPT 202; notes on Six Variations on "The Squid Jiggin' Ground" (piece that Eggleston is writing); notes on Quartet for Flute and Strings; Lesson I for viola; Liszt finger exercises; closed and open broken triads; excerpts from different composers for piano (one system each); left-hand finger exercises for the piano; major-minor (right hand) and minor-major (left hand); octave patterns; contrary dominant sevenths; twelve-step trills; intervals; stretch chords; broken triads in two keys; five-finger workout; major scales and cadences II; "In and Out"; melodic minor scales; "Left-Hand Challenge"; "Right-Hand Challenge"; "Five Fingers on the Go"; closed and open broken triads; lesson no. 13 from Berklee correspondence course; graded assignments; class notes from COMP 211

100 Sketches for pieces to be written; copied pieces; miscellaneous pages from pieces or recopied pieces (missing first pages); scores from Eastman classes (1958) 


\section{Box Folder Description}

101 Miscellaneous: business card (Eggleston); "Music of Anne Elisabeth Eggleston" summary; notes on basic painting and drawing; notes on oil painting; Eggleston quotes; letter by Eggleston to Isobel Kristigan (25 March 1979) requesting permission to send parts and scores for Let's Celebrate to the CMC; parts for Let's Celebrate; letter from $\mathrm{H}$. A. Mutsaers from the CMC (7 December 1976) requesting permission on behalf of Leister's Music Ltd. to purchase a copy of "Christmas Song"; letter from Keith MacMillan, general manager at the CMC (6 December 1976) requesting that she update her entry for the French edition of Contemporary Canadian Composers; letter from Sister M. Stanislaws of the Toronto Learning Centre (29 March 1977) requesting biographical information for a volunteer project for the Canadian Music Teachers' Centres; note by Eggleston that she has sent copies of Jean Southworth's write-up of piano music of Ottawa composers to Sister M. Stanislaws and Miss Mary MacLean; article from the Canadian Composer (January 1975) "Is There Still a Role for the Recitalist-Composer?" by Gerald Levitch; Christmas with notes in treble clef and chord above pitches; letter from Mary H. MacLean (24 May 1977) requesting three copies of the Sketches for Ottawa; program for the Boris Roubakine Memorial Ceremony with short written tributes by Anne and Wilfrid Eggleston

102 Musical works: Hurry! Hurry! Hurry! for piano; Put This in Your Pipes and Smoke It for voice and piano; Requiem: In Memory of My Father for voice and piano (words by R. L. Stevenson; December 1986); Vestigia for four voices (words by Bliss Carman): different versions; From Catty! for voice and piano; Fanfare for CAMMAC for three treble instruments; Glass and Concrete Towers for piano (commissioned by Suzanne Chapin May 1977); newsletter from the Canadian Citizenship Federation (July 1977) includes We Are One for voice and piano (words by Magdalena Eggleston); A Poet's Prayer for voice and piano; Ascent for carillon; Foursquare; It's Great to Be a Canadian for voice and accompaniment (chords written above melodic pitches) (words by Magdalena Eggleston)

103 Humorous drawings by Glenn Morley related to music

\begin{tabular}{|c|c|}
\hline 104 & Thoughts or quotes by Eggleston on file cards \\
\hline 105 & Thoughts or quotes by Anne and Wilfrid Eggleston on file cards \\
\hline 106 & Thoughts or quotes by Anne, Wilfrid, and Magdalena Eggleston on file cards \\
\hline 107 & Thoughts or quotes by Wilfrid Eggleston on file cards \\
\hline 108 & Written anecdotes related to music; anecdotal clippings related to music \\
\hline 109 & Thoughts and notes on various topics (not just music) \\
\hline 110 & $\begin{array}{l}\text { Arrangements: St. Anthony Chorale by Haydn/Brahms arranged for guitar; Allegro in G } \\
\text { Minor by Giuliano arranged for piano; Vive la canadienne arranged for flute, cello, and } \\
\text { piano; Synfonia XI by J. S. Bach arranged for violin; recopied scores (lied, folk songs of } \\
\text { different nationalities); Preludio by Mauro Giuliani arranged for keyboard; They All Call It } \\
\text { Canada (But I Call It Home) by Freddy Grant arranged by Leslie R. Bell and Anne Eggle- } \\
\text { ston for voice, soprano recorder, alto recorder, treble recorder, bass recorder, and piano }\end{array}$ \\
\hline 111 & $\begin{array}{l}\text { Musical works: Let's Celebrate (sketch?); Song of Love (piano with text above right-hand } \\
\text { part); Seven Variations for piano (Grade } 7 \text { list B); Triple-Trouble for piano; Lullaby for low } \\
\text { voice and piano; Ethnic Dance (adjudicator comments; for solo guitar; Grade } 6 \text { list C); } \\
\text { Deck the Halls for piano; It Came upon the Midnight Clear for piano; Carol of the Bells } \\
\text { for piano; God Rest Ye Merry for piano; At Random for piano; A Nineteenth-Century } \\
\text { Waltz to Elizabeth Gault for piano; Darling Nellie Grey for piano; Lincolnshire Poacher for } \\
\text { piano; O Where O Where for piano; Kol jauns nevedes buvau for piano; Singing Triads } \\
\text { for piano; Hold One Play Four for piano; Meadowlands for } 4 \text { instruments; Olga Is Our } \\
\text { Hero Today for voice and piano; The Answer Could Never Be Yes for voice and piano; } \\
\text { The Squid-Jiggin' Ground for voice and piano; Galop Joramletta for Three Instruments; } \\
\text { Serenade for Unaccompanied Cello; What Child Is This for piano; Good King Wenceslas } \\
\text { for piano; A Christmas Tree for the Birds for piano, with words in between two staves; } \\
\text { Skippy Jumps for piano; If You Don't Love Cats for voice and piano (notes inserted); } \\
\text { Ghost Town for voice and piano (notes inserted); My Lute Awake! for two sopranos and } \\
\text { one alto; O See What Troupes of Nymphs for two sopranos and one tenor; La cigale by } \\
\text { Remi Belleau for four voices }\end{array}$ \\
\hline
\end{tabular}




\section{Box Folder Description}

112 Musical works by other composers: Dehliah arranged by E. Levy; On Citadel Hill (accompaniment by Nancy Thornton); Eggleston Variations by Bobo Sparks for piano; In Memoriam Lester Pearson by David Hemsley for viola and piano; There Is No Rose by David Houldridge (Words: anon.; ca. 1420) for unaccompanied choir; Resurgence by Lloyd Trueman for voice and piano; Two-Part Invention for Piano No. 1 by David Hemsley; Ideas off a Tune for Piano by David Hemsely; songs with piano accompaniment

10113 Scrapbook: cards (birthday, thank you, get well, etc.); one personal letter

114 Scrapbook with press clippings on Eggleston or performances of her works; Ottawa Journal, 30 March 1966 ("Lullabies of Eugene Field"); CBC Times, 26 March to 1 April 1966 ("Lullabies of Eugene Field"); "Music Provides Background for Anne Eggleston's Career" by Kit Irving, Ottawa Journal, 19 July 1965; "CAMMAC Reunion Nov. 28-29," Ottawa Journal, 21 November 1970; "Musical Arts Scholarship," Ottawa Journal, 14 November 1970; program for Musical Arts Club concert, 18 November 1970, at the Unitarian Church (includes Eggleston's Blue Flute performed by Judy Tant); "Flute Pieces, Songs in Premiere at Concert" by Lauretta Thistle, Ottawa Citizen, 19 November 1970; concert program for the Ottawa Recorder Players on 4 April 1971 at the National Research Council; several clippings that Eggleston was the hostess for meetings of the Musical Arts Club; "Ottawa Artists in MAC Concert," Ottawa Journal, 30 March 1963; concert program of Christmas Music by the Studio Singers under the direction of Dorothy Lampman McCurry at Academic Hall, University of Ottawa, 15 December 1962; "Ottawa Girl Top Composer" by Jane Becker, Ottawa Journal, 2 May 1962; "Award-Winning Young Composer Gives Prize Back to Buy Trophy," Ottawa Citizen, 2 May 1962; "Below the Hill" by Tim Burke, Ottawa Journal, 30 March 1960; "Canadian Piano Quartet Makes Exciting Evening" by Lauretta Thistle, Ottawa Citizen, 22 November 1963; "Musical Matters: Chance to Hear Winning Singer" by Jean Southworth, Ottawa Journal, 22 February 1964; press clippings for when the Piano Quartet will be broadcast; press clippings for the Quatuor canadien, includes mention of Eggleston's Piano Quartet (La Presse Montreal 2 March 1964 by Jean Vallerand; Gazette, 2 March 1964 by Frances Goltman); program notes for the Canadian Piano Quartet, 1 March 1964, with Eggleston's Piano Quartet; Ottawa Philharmonic Orchestra program for 1959-1960; "Musical Matter: Second Hit Show for Regis Group" by Jean Southworth, Ottawa Journal, 19 March 1960; program for Canada Music Week, ORMT Ottawa Branch concert, 29 November 1969, at the Unitarian Church; press clippings for concert at the National Gallery, 14 May 1967 (Ottawa Journal, 6 May 1967; Ottawa Citizen, 6 May 1967); "Anne Eggleston Compositions at Lakeside," Ottawa Journal, 4 June 1960; "Concerts at Lakeside," Ottawa Citizen, 14 June 1960 (mentions that works by Eggleston will be played 17 August); "Orchestra Concert Planned for Festival's Final Week," Ottawa Journal, 13 August 1960; "Last Festival Week Offers Comedy, Recitals, Films," Ottawa Citizen, 13 August 1960 (mentions that Eggleston will play some of her pieces with the orchestra); "Ottawa Composer," Ottawa Journal, 6 May 1967 (mentions that the Musical Arts Club will honour Eggleston with a concert devoted to her works at the National Gallery); "Music by Ottawa Composer," Ottawa Citizen, 6 May 1967; "Program of Works by Anne Eggleston," Ottawa Journal, 13 May 1967; "Versatile Ottawa Composer Experiments in Many Styles" by Lauretta Thistle, Ottawa Citizen, 13 May 1967; concert program for "In Celebration of Canada's Centennial, the Music Arts Club of Ottawa Presents the Music of Anne Eggleston," National Gallery Auditorium, 14 May 1967; "Un programme consacré au compositeur Anne Eggleston," Le Droit, 13 May 1967; "City's Composer's Work Sets Concert Theme" by Lauretta Thistle, Ottawa Citizen, 15 May 1967; radio highlights for Fanfaron for Orchestra (Ottawa Journal, 31 January 1968; CBC Times, 27 January to 2 February 1968); "Facts and Fancies: Conversation Piece" by Harriet Hill, Montreal Gazette, 28 March 1960; "Former South Alberta Girl Is Promising Composer" by C.F.S., Lethbridge Herald, 28 March 1960; article by Harriet Hill, Gazette, 5 August 1966; concert program for the Concerts JMC Orford: Quatuor Canadien de Piano (summer 1965); advertising for the New Piano Quartet concert featuring Egglston's Piano Quartet, 17 October 1966, Queen's University; concert at Queen's mentioned in press clipping from Ottawa Journal, 22 October 1966; "Ovation Accorded to Composer," Kingston Whig-Standard, 18 October 1966 (general information about the concert); "Ottawa Composer Honored at Concert" by E.J.S., Ottawa Journal, 15 May 1967; "Anne Eggleston Writes Pieces for CAMMAC," Ottawa Journal, 27 May 1967; "CAMMAC's Centennial Concert Offers New Commissioned Works," Ottawa Citizen, 27 May 1967; "Folk Songs, Madrigals In CAMMAC Program," Ottawa Journal, 3 June 1967; "Musicians Stage Special '67 Show" 
by C.R., Ottawa Journal, 6 June 1967; concert program for the Musical Arts Club, 24 March 1969; "Club Gives Program of Unusual Interest" by E.J.S., Ottawa Journal, 25 March 1969; "Music and Theatre: Arranging Bach's Music Can Be a Tricky Business" by Lauretta Thistle, Ottawa Citizen, 22 March 1969; "Anne Eggleston Pieces to Have Premiere," Ottawa Journal, 22 March,1969; "Canadian Compositions Featured in Concert by Musical Arts Club," Ottawa Citizen, 22 March 1969; "Concert to Aid Scholarship Fund," Ottawa Journal, 15 March 1969; "СBO: Ottawa Sketches," Ottawa Journal, 29 December 1966; Gazette, 30 December 1966; CBC Times, 30 December 1966; Ottawa Journal, 30 December 1966

11115 Scrapbook with press clippings: articles on Magdalena Eggleston's first book, Mountain Shadows; other female writers (1954-1955); modelling show for gowns from 1920s, one modelled by Magdalena Eggleston; articles on Joan Hardy, Miss Ottawa Rough Rider, and Alderman Wilburt Hamilton greeting the sixteen band majorettes of the Montreal Alouettes (November 1955); gala showing of styles in season (October 1955)

116 Workbooks: Combermere for piano (July 1948); Seals' Lullaby for voice and piano; The Wind for piano; Violin Solo; Scherzo for piano; Arabia for voice and piano (four pages) words by Walter de la Mare; Variations on the Motive B3-E4-G4-A\#4-F4-C\#5-D5-A4F4-Ab4-C4-Eb4 for piano; two more drafts of Arabia for voice and piano; Autumn Wind for voice and piano words by M. Raskevich (1951); I Would Be Free for voice and piano, words by Lloyd Roberts; two drafts of To the Lute Player for voice and piano, words by A. Lampman; Thirteen Ways of Looking at a Blackbird for voice and piano, words by Wallace Stevens; Sonatina for piano; Aš paemiau mergužile (Luthuanian folk song) for voice and piano; sketch of Piano Sonatina?

12117 Workbooks: first book, sketches; second book, sketches, includes Armenian Lullaby, Jewish Lullaby, Lullaby of the Sea, I Will Praise God

118 The Wood Carver's Wife, folk opera in one act, words by Marjorie Pickthall; press clipping of Michelangelo's Pietà at New York World Fair (Ottawa Journal, 21 April 1964); libretto

119 Rhapsody for Violin and Piano: scores and parts (manuscripts)

120 Sonatine for Piano (1964-1965) manuscript

121 Variations on a Theme of Bartok for violin and piano (fourteen variations): piano reduction of orchestra score; sketches; manuscripts; notes

13122 Three Pieces for Orchestra (April 1956): parts and copies

123 Three Pieces for Orchestra (April 1956): parts (manuscripts and copies)

124 Three Pieces for Orchestra (April 1956): score (copy)

$14125 \quad$ Piano Quartet (1954-1955; copyright 1972): score and parts (copies)

126 String Quartet (1964-1965): score and parts (drafts and copies)

127 Scores: André's Lullaby for piano; Night on the Ottawa River for S.A.T.B. and piano, words by A. S. Bourinot; Song to the Four Seasons for unison chorus and piano, words by P. G. Hiebert; Johnny for S.A.T.B. and piano, words by Lilian Found; I Will Find My Love at Expo for treble voice and piano; To Expo for treble voice and piano; The Reed Player for medium voice, alto recorder or flute, and piano, words by Duncan Campbell Scott; Send Her on Along for voice and piano, melody and words collected by Charles Marchand; Apriliana for S.A.T.B. and piano, words by Bliss Carman (1: "Now the Lengthening Twilights Hold"; 2: "Daffodil's Return"; 3: "The Flute of Spring"; 4: "Under the April Moon"; 5: "April Now in Morning Clad") The Old Chateau: Theme and Eight Variations for Piano Solo (Grades 7-8); To the Lute Player for voice and piano, words by Archibald Lampman; Christmas Morn for voice and piano, words by Blanche Bishop; Good Christmas Bells for piano and voice, words by A. B. De Mille; Ottawa Theme for piano 
Box Folder Description

128 Scores: The Happy Journey for Cello, Viola, Violin and Clarinet (nine short movements), score and parts; Thirteen Ways of Looking at a Blackbird for voice and piano (song cycle), words by Wallace Stevens; Six Pieces in Popular Style for solo instrument; $A u$ tumn Wind for voice and piano, words by Magdalena Eggleston; Moon Magic for voice and piano, words by A. S. Bourinot (July 1954; revised March 1960); L'Âne de Jean for voice and piano; The Mirror for voice and piano, words by A. A. Milne; Arabia for voice and piano, words by Walter de la Mare; Thoreau at Walden for voice and piano, words by Wilfrid Eggleston; Jewish Lullaby for voice and piano, words by Eugene Field; Norse Lullaby for voice and piano, words by Eugene Field; Lullaby by the Sea for voice and piano, words by Eugene Field; Japanese Lullaby for voice and piano, words by Eugene Field; Armenian Lullaby for voice and piano, words by Eugene Field; Antique Suite for two alto recorders and harpsichord ("Prelude," "Minuet," and "Sicilienne"; "Gavotte" and "Musette"; "Finale")

15129 Autumnal Clouds: Poem for Baritone and Orchestra, words by John Gould Fletcher: score (manuscript)

130 Autumnal Clouds: Poem for Baritone and Orchestra, words by John Gould Fletcher: parts (manuscript)

131 Autumnal Clouds: Poem for Baritone and Orchestra, words by John Gould Fletcher; reduction for voice and piano (manuscript) and poem

132 Sketches, fragments, untitled works, misplaced pages from other scores

Arrangements and copies: Christmas Morning for two voices; Vive la canadienne for two pianos (incomplete); Hindemith Fugue in $G$ for three instruments; Chopin's Etudes for Piano; Twelve German Dances by Schubert for two pianos; Ah! Qui me passera le bois? for S.A.T.; Gai le rosier for S.A.T. (incomplete); Vive la canadienne for S.A.T. (incomplete); Dans tous les cantons for S.A.T.; Petit Rocher for S.A.T. (incomplete); My Lonely Heart, Quebec City 1918 for two sopranos, one alto, and piano; I Shall Never Forget for soprano, alto, and piano, words by Douglas Leechman; The Christ Child's Lullaby for two sopranos, one alto, and piano; In a Pleasant Little Valley (Slovenian folk song) for piano duet; I Went into the Garden of Nuts for solo instrument and piano; Come with Me from Lebanon for solo instrument and piano; Come to the Farmyard for solo instrument and piano; The Lord Is My Strength for solo instrument and piano; Intermezzo opus 118, no. 2 by Brahms for violin, viola, and piano; Intermezzo opus 117, no. 1 by Brahms for viola and piano; Serenade from Rachmaninoff for viola and piano; Andante from Piano Sonata opus 1 by Brahms for viola and piano; Waltz in A Minor by Chopin for viola and piano; Prelude no. 8 from Twelve Short Preludes by J. S. Bach for violin and piano; Mazurka opus 67, no. 4 by Chopin for violin and piano

134 Scores: Seven Studies in Search of a Title for piano; Johnny Marie for voice and piano (unfinished); In a Pleasant Little Valley for piano duet; Now the Lengthening Twilights Hold for S.A.T.B. and piano, words by Bliss Carman; Everyone Everywhere Come Come Come! for voice and piano; Among the Millet for voice and piano, words by Archibald Lampman; Seven Studies in Strange Scales for piano; Sketches of Ottawa for piano (1962) ("Parade on Parliament Hill"; Canoeing on the Canal"; "Running in Rockliffe Park"; "Dawn on Dow's Lake"; "The Bank Street Bus"; "Tiptoeing through the Tulips"; "The Peace Tower Clock Strikes Thirteen"; "Crossing the Champlain Bridge"; "Gazing at the Gatineau Hills"; "The Dashing Diplomat's Dance"; "By the Colonel By Fountain"; "Merrymaking on the Mall"); Come with Me from Lebanon, arranged by Eggleston for solo instrument and piano; I Went into the Garden, arranged by Eggleston for solo instrument and piano; Christmas Song for voice and piano, words by Bliss Carman (November 1960); Sanctus for S.A.T.B.; Love Is Hell for solo voice, words by Magdalena Eggleston; Guitar Boy for solo voice (only first page); Silver Birch for four voices (incomplete); I Was in the Moon of Winter Time for piano (incomplete)

135 Fanfaron for Orchestra: scores (manuscript and copy)

$136 \quad$ Unfinished vocal works

137 Interlude for Orchestra: score and parts (manuscripts)

$17137 \quad$ Unidentified work for piano in seven movements: manuscript and copy 


\section{Box Folder Description}

138 Scores: Troubadour for voice and piano, words by A. S. Bourinot; Songs from Deepwood for voice and piano, words by A. S. Bourinot ("Daybreak at Deepwood"); Sunflowers; Moon Magic; Now Is the Season

Scores: King Herod and the Cock for three high voices; Theme for Etude No. 3 for piano (three staves); Be Steadfast to Thine Own from a Gorgeous Gallery of Gallant Inventions for two high voices; The Huge Heap of Cares for two high voices; Coventry Carol for S.S.A; The Bird and the Hour for S.S.A., words by Archibald Lampman; Christmas Cards for voice and piano? (one-page sketch), words by Magdalena Eggleston; Chorale for piano (one-page sketch); The False Young Man for piano; The Scarborough Settlers Lament for piano; Duffy's Hotel for piano; The Honest Working Man for piano; The Ferryland Sealer for piano; Combermere for piano; Prelude-Mazurka on the Theme by H. Hints for piano by A. Dobell to Anne Eggleston; Where Can You Be? for voice and piano; You Never Said Goodbye to Me for voice and piano; Since You're Not Here for voice and piano

140 On Citadel Hill: Theme and Six Variations for string orchestra (John Adaskin School Music Project): score and parts (copies)

141 Sketches; fragments; untitled works; Merchandise for voice; Get Together Rag for piano; Lullaby Thou Little s my Child for three upper voices; I Call Your Name for piano and voice; Harpsichord Solo for harpsichord; Frolic for clarinet, horn, and piano; Six Pieces in Popular Style; The Peace Tower Clock Strikes Thirteen for piano?; Themes from Gilles Quaille: The Old Château for piano? (one-page sketch); Gazing at the Gatineau Hills for piano? (one page and one system sketch); Vortex Variations for piano (one page); corrected composition assignments

142 Pedagogy material for music students; pedagogy materials for piano students

143 Salute to the Sun or Suryanamaskar: draft (ten pages); copy (thirteen pages); notes and letters

144 Musical works by other composers: manuscript; copies; published score (annotated); Watermelon and Friends: A Little Suite for Piano by Linda Niamath (1981); Variations on an Original Theme for piano by Gloria Swisher (1963); Waltzling for piano by John Weinzweig (1939); The Holly for voice and piano by Martha Jackson, words by Edith King; Prairie at Evening for voice and piano by Percival Price, words by Wilfred Eggleston; Rigadon for piano by Robert Fleming (1952); Piano Sonata by John Weinzweig (1950); Le tombeau de Couperin by Maurice Ravel

145 One sheet with autographs of different musicians

146 Certificates: Certificate of Merit from the Ottawa Music Festival Association for a $\$ 100$ scholarship (class 119, section: composition) (May 1962); Berklee Correspondence Course: satisfied requirements fortwenty-five-lesson correspondence course (June 1968); University of Toronto, Royal Conservatory of Music, Grade 2 Piano Examination (June 1966) for Anne B. Porter; University of Toronto, Royal Conservatory of Music, Grade 3 Theory Examination (June 1949); University of Toronto, Royal Conservatory of Music, Grade 5 Theory Examination (February 1952); University of Toronto, Royal Conservatory of Music, Grade 2 Theory Examination (February 1949)

18147 Artist diploma from the University of Toronto (30 October 1956)

148 Interlude for Small Orchestra: score (copy)

Note: The collection consists of eighteen boxes divided into 148 folders. Some of the folders (box 5 , folder 58 ; box 6 , folders $67,68,69$, and 72; box 7 , folder 81) have been relocated to the Wilfrid Eggleston Fonds (R4882-0-3-E). Folders 99, 100 , and 101 are placed after 103 in box 8. Folder 137 is duplicated in boxes 16 and 17 , but with different materials. 


\title{
REFERENCE LIST
}

Canadian Music Centre. "Anne Eggleston.” http://www.centremusique.ca/ apps/index.cfm?fuseaction=composer.FA_dsp_biography\&authpeopleid= $215 \& b y=\mathrm{E}$.

Eggleston, Anne. Piano Quartet. Musica Camerata Montreal. Independently released: Pointe-Claire, Quebec, 1996.

The Canadian Encyclopedia. "Eggleston, Anne." Leonard Isaacs and Betty Nygaard King. http://www.thecanadianencyclopedia.com/index.cfm?PgNm= TCE\&Params $=\mathrm{U}_{1}$ ARTUooo110 7 .

\begin{abstract}
Canadian composer Anne Eggleston had an active career as both composer and piano pedagogue. In many of her works, such as Sketches of Ottawa, she sought to bridge the gap between these two interests. By examining the Anne Eggleston Fonds (MUS 282), acquired by Library and Archives Canada in 1997, we can begin to understand the personality of this remarkable composer and her commitment to piano pedagogy. Her teaching materials and her devotion to private students, as well as her affiliation with music organizations, paint a full picture of this important Canadian composer and pedagogue.
\end{abstract}

\section{RÉSUMÉ}

Parallèlement à ses activités créatrices, la compositrice canadienne Anne Aggleston a mené une carrière active en pédagogie du piano. Plusieurs œuvres, comme Sketches of Ottawa, tentent de combiner ces deux préoccupations. L'examen du Fonds Anne Eggleston (MUS 282), acquis par Bibliothèque et Archives Canada en 1997, aide à saisir la personnalité de cette compositrice remarquable et évaluer son engagement envers la pédagogie du piano. Ses notes de cours et son dévouement envers ses étudiants en privé, de même que son adhésion auprès d'organisations musicales, dessinent un riche portrait de cette importante compositrice et pédagogue. 